\title{
Siring Piere Tendean: Examine Patternans of Community Activity in the Public Room
}

\author{
Bambang Subiyakto ${ }^{1 *}$ Mutiani $^{1}$ Aida Afrina ${ }^{1}$ \\ ${ }^{1}$ Social Studies Education Department, Faculty of Teacher Training and Education, Lambung Mangkurat University, \\ Banjarmasin, Indonesia \\ ${ }^{*}$ Corresponding author. Email: bambangsb@ulm.ac.id
}

\begin{abstract}
The need for people especially those who live in urban areas is public open space. Public open space can be used by the community for some positive activities such as livelihood centers, recreation, and social. In Banjarmasin, one public space that is utilized by the community is Siring Piere Tendean. Siring Piere Tendean became a public space that was favored by the community especially on weekends. This article aims to describe the pattern of community activities in Siring Piere Tendean in the context of the Siring Piere Tendean public space. A qualitative approach with a descriptive method is used to describe research data. Data collection techniques through three stages namely; participatory observation, structured interviews, and documentation. Analysis of Miles and Huberman's interactive model data so that the data obtained is saturated.community activity in Siring Piere Tendeandocumented as important activities, choices, and social. This is based on Siring PiereTendean managed by the government and positive space. First, important activity, making Siring Piere Tendean as a place for owners/drivers klotok make a living. Second, the activity of choice, for people to spend time on recreation. Third, social activities are seen from the interaction between klotok drivers, traders, visitors, managers, and social communities who spend time on weekdays and weekends.
\end{abstract}

Keywords: Public space, Siring Piere Tendean, and community activities.

\section{INTRODUCTION}

Siring Piere Tendean is one of the resorts chosen by the Banjar people to spend the weekend. Siring Piere Tendean is located in Kelurahan Kampung Gedang, Central Banjarmasin District. Siring Piere Tendean is a public space that is used by the community for tourism, economic, social, and sports activities. Siring Piere Tendean often held various events such as; food festivals and ornamental jukung festivals, exhibitions aimed at bringing home the industry to life in the city of Banjarmasin.

The potential of the Siring Piere Tendean region is optimized by maintaining the continuity of plants in the Green Open Space (RTH), increasing activity in the form of events, and organizing traders who sell [1][2]. This subject was chosen so that Siring Piere Tendean is comfortable for visitors. Siring Piere Tendean as open public space can accommodate the needs of the community. The Siring Piere Tendean public space has a place that is considered special by the public, the Anno home. Anno House is considered unique and a favorite place for visitors to take pictures. Also, another special place is the View Tower which provides a place for the public to see the beauty of the city of Banjarmasin and its Martapura river from the top of the tower [3].

As part of the public space Siring Piere Tendean is characterized by three things. These three things are responsive, democratic, and meaningful. First, the meaning of responsiveness in the sense of public space is understood that Siring Piere Tendean is utilized by the community for activities and broad interests. Second, democratic meaning is explained that Siring Piere Tendean can be used by every level of society. In this sense, there are no social status restrictions that can dominate the use of Siring Piere Tendean. The third is meaningful which means that Siring Piere Tendean has a link between humans, space, in a social context [4][5][6] The ideal meaning of public space attached to the Siring Piere Tendean in a factual context is constrained by the chaotic economic activities that are dominated by street vendors. This is because every week the Siring Menara Pandang is always crowded with people.

Based on a preliminary study presented by Spartz (2011) that public space is represented by meeting the needs of the audience. Thus, there should be no domination by one party that benefits from public space even if it is limited to the location of livelihoods. Therefore, it is necessary to maintain public space by stakeholders for mutual convenience. This article aims to describe the patterns of community activities in Siring Piere Tendean in the context of public space. This is because the activities at Siring Piere Tendean have three different types of activities by visitors at Siring Piere Tendean.

\section{RESEARCH METHODS}

This study aims to describe the activities of the society in public spaces precisely in Siring Piere Tendean, Banjarmasin. Qualitative approaches and descriptive 
methods are used in research. The study was conducted in the city of Banjarmasin, precisely on Jalan PiereTendean. Research subjects include: Burhan as the owner and head of the Banjarmasin klotok (motorized boat) group, Sabani, the owner of 8 klotok in Siring Menara Pandang, Saifullah, visitors who work as employees, Liana, a visitor who is a housewife, Nurul Hidayah is a trader who sells every day at Siring Piere Tendean.

The entire research subject was determined by purposive sampling technique [7]. The in-depth interview technique was carried out to explore data regarding community activities in public spaces. Of course, in digging into data three steps are carried out, observation alongSiring Piere Tendean, and documentation of all activities that occur Amongklotok owners, visitors, and traders. Model of Miles andHubermanused for data analysis techniques, starting from: (1) data collection; (2) data reduction; (3) data presentation; (4) drawing conclusions and verification [8]. This is intended so that researchers can classify the relationship of research findings in a logical sequence of events. Data validity testing techniques are needed to see the validity and reliability of the data [9][10].

Techniques performed (1) Extension of work time and observation in the field. The study was conducted, 21 - 30 April 2019. However, observations were extended for a week (5 - 11 May 2019). This is done concerning the data needed in the form of a description of the public interest coming to enjoy the public space, (2) Triangulation (triangulation), is to use the widest variety of sources, methods, from researchers, and theories to provide corroborative evidence [11]. Triangulation becomes a procedure to see the saturation point of data collected. The stages are carried out by comparing the observational data and the results of interviews and the results of study documents and various other sources that support the research objectives.

\section{RESEARCH RESULTS AND DISCUSSION}

Siring Piere Tendean is one of several public spaces as well as tourist attractions that are utilized by the Banjar community. For the Banjar community, Siring Piere Tendean has a building icon that is well known to the community, the Menara Pandang and Rumah Anno. The Siring Piere Tendean Complex is managed by the Banjarmasin city government, especially the Banjarmasin City Culture, Tourism, Youth, and Sports Service. Based on its category Menara Pandang is a positive space because it has the characteristics of being managed by the government and forms of natural / semi-natural space, public space, and public open space [12][13]. As a public space, Siring Piere Tendean consists of three main activities, namely; important (main), choice, and social activities.

The first, important activities (main)/necessary activities are defined as routine activities carried out because of the necessity to meet primary needs. Important activities are attached to all klotok owners who hang out in the Menara Pandang tower. The owner and "driver" klotok hereinafter referred to as "uncle klotok" is the main occupation for those who tether the klotok at the Siring Piere Tendean dock. Klotok drivers do not have side income or other work. Every day they only spend time waiting for individual passengers and groups (in the form of charter).

Second, optional activities are defined as activities carried out when there is an opportunity or an appropriate time. This activity is carried out by the community when the situation in the public space is comfortable to spend free time outside of daily activities. Community choice activities are related to recreational activities. The public interest in spending time at Siring Piere Tendean is increasing every weekend. This is because Siring Piere Tendean provides tourist attractions from river transportation, Menara Pandang, Anno House, floating market on the pier, and typical Banjar culinary tours. Increased public interest in selected activities on weekends makes Siring Piere Tendean loved by street vendors (PKL). However, to maintain comfort often encountered raids from Satpol PP officers to curb the street vendors. The following is an overview of selected activities at Siring Piere Tendean.

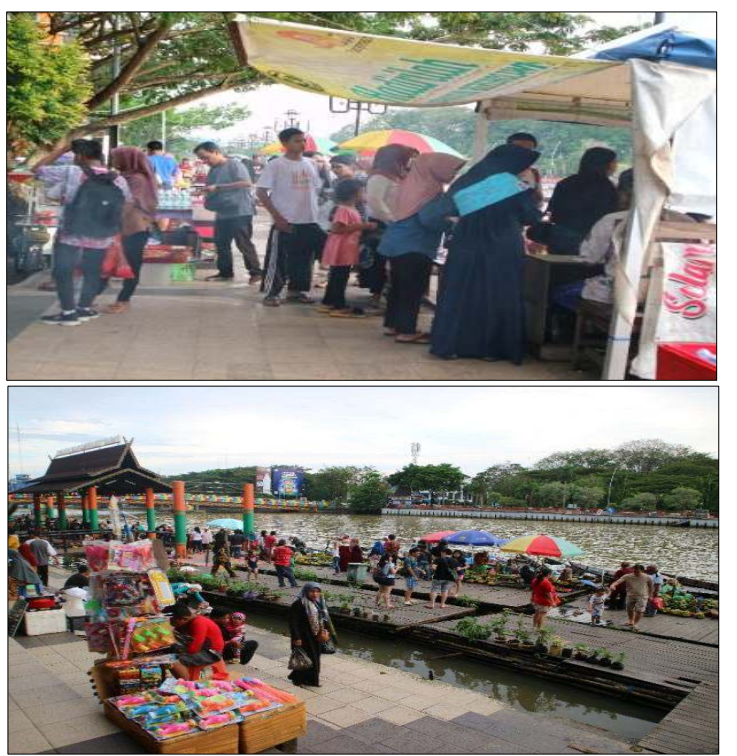

Figure 1 Selected Activities at Siring Piere Tendean Source: Personal Documentation (2019)

Selected activities that emphasize recreation make community visitors as local tourists. Recreation at Siring Piere Tendean is made by the community as a place to relax and clear body and mind after a day of activities. Based on the results of the interview visitor Liana (37 years) "we came in a group to make a pilgrimage to the tombs so that all of us go here to spend the vacation time for the children right soon to go to school so it is taken on vacation". The meaning of the activity is that the Siring Piere Tendean area is a place for the community to carry out various activities such as walking along the siring on the edge of the river, exercising especially on Sunday mornings, as a good place to take pictures and other activities.

Third, Social activities are defined as activities that involve interaction with other parties around public space locations. 
Activities tend to be unplanned in their implementation due to important activities and selected activities. Siring Piere Tendean becomes a public space that is not only used as a tourist attraction but also a gathering room for young people. Siring Piere Tendean public space as public land where the community can carry out functional public activities and side activities. Social activities that arise in the public space of Siring Piere Tendean are seen based on interactions between klotok drivers, street vendors, visitors, and social communities that are active.

Social activity in Siring Piere Tendean is dynamic because it is not dominated by any social group. Siring Piere Tendean is always packed with people from all walks of the weekends. Everyone in the synergy so that no one is harmed. The continuation of social activities in Siring Piere Tendean is indirectly affected by physical changes in the landscape, as well as improvements in infrastructure to provide access. The access provided includes facilities and generosity for the community so that various activities can be carried out in Siring Piere Tendean.

The pattern of community activities on the use of public space in Siring Piere Tendean is based on observing its activities and movements. Both of these patterns are part of the aspects studied to analyze the behavior setting. Behavior setting analysis is carried out using the following criteria: 1) Activity person (person), 2). Patterns of behavior (standing pattern of behavior) or behavior that is repetitive, 3) Physical limits (physical milieu), 4) Relationship between boundaries and patterns of activity, 5) Power territory (territory), and 6) A certain time at when the activity takes place (temporal) [14][15][16].

The pattern of community activities in Siring Piere Tendean is supported by functions and land use. Both of these supports strengthen the public space in Siring Piere Tendean that has a positive impact on community activities. The physical form of the Siring Piere Tendean is interestingly designed and added to the building and serves as a tourist attraction. Thus the Siring Piere Tendean accommodates several functions with a variety of different character activities. Structured public space must be based on important activity patterns, choices, and social.

\section{CONCLUSION}

Community activities in Siring Piere Tendeandocumented as important activities, choices, and social. This is based on Siring PiereTendean managed by the government and positive space. Each activity characterizes a different situation. The first important activity, making Siring Piere Tendean as a place for klotok owners who hang out to make a living without any income or other side businesses. Second, activity choices, characterize the priority level of activities undertaken. Banjar people who spend their time have a choice when they come to Siring Piere Tendean or vice versa for recreational purposes. Third, social activities, characterize relationships in parallel with important activities and activity choices. In Siring Piere Tendean social activities can be seen from the interaction between klotok uncles, traders, visitors, managers, and social communities who spend time on weekdays and weekends.

\section{REFERENCES}

[1] R. Faedlulloh, D., \& Prasetyanti, "Menggagas Ruang Publik Berbasis Demokrasi Deliberatif: Studi Dinamika Pengelolaan Ruang Publik Terpadu Rumah Anak (RPTRA) di Jakarta Utara," Spirit Publiik, vol. 12, no. 2, pp. 43-60, 2017.

[2] N. Puspasari, R., Ernawati, J., \& Suryasari, "Pola Aktivitas Pada Ruang Publik Taman Bungkul Surabaya," Arsitektur, vol. 4, no. 2, 2016.

[3] E. W. Ajidayanti, A., \& Abbas, "Utilization of Tourism Bekantan Mascot as a Learning Resource On Social Studies," Innov. Soc. Stud. J., vol. 1, no. 1, pp. 78-86, 2019.

[4] R. J. Surayuda, "Pusat Komunitas dan Kontestasi Memori Kolektif: Studi Kasus Ruang Publik Terpadu Ramah Anak (RPTRA) Kenanga di Cideng, Jakarta Pusat," Masy. J. Sosiol., pp. 233236, 2016.

[5] \& S. Sugiyanto, E., "Optimalisasi Fungsi Ruang Terbuka Hijau Sebagai Ruang Publik di Taman Ayodia Kota Jakarta Selatan," J. Sos. dan Hum., vol. 2, no. 3, 2017.

[6] M. Subiyakto, B., \& Mutiani, "INTERNALISASI NILAI PENDIDIKAN MELALUI AKTIVITAS MASYARAKAT SEBAGAI SUMBER BELAJAR ILMU PENGETAHUAN SOSIAL," Khazanah J. Stud. Islam dan Hum., pp. 137-166, 2019.

[7] A. M. Yusuf, Metodologi Penelitian Kuantitatif, Kuaalitatif \& Penelitian Gabungan. Jakarta: Prenadamedia Group, 2017.

[8] B. Afifudin \& Saebani, Metodologi Penelitian Kualitatif. Bandung: Pustaka Setia, 2012.

[9] J. Creswell, Research Design: Pendekatan Kualitatif, Kuantitatif, dan Mixed. Yogyakarta: PT Pustaka Pelajar, 2010.

[10] M. . Richards, K.A., \& Hemphill, “A Practical Guide to Collaborative Qualitative Data Analysis," J. Teach. Phys. Educ., pp. 225-231, 2018.

[11] I. Gunawan, Metode Penelitian Kualitatif Teori dan Praktik. Jakarta: Bumi Aksara, 2014.

[12] Y. Pratiwi, "Transformasi Fungsi Ruang Terbuka Publik di Perkotaan Studi Kasus: Taman Pedestrian Kecamatan Tenggarong, Kabupaten Kutai Kertanegara, Kalimantan Timur," NALARs, vol. 15, no. 1, pp. 63-72, 2016.

[13] A. Russ, "Development of Ecological Place Meaning in New York City," J. Environ. Educ., vol. 46, no. 2, pp. 73-93, 2015.

[14] A. Utami, P.K., Mugnisjah, W. Q., \& Munandar, "Partisipasi Masyarakat Kota Berbasis Manfaat dalam Membentuk Taman Publik Ramah Anak," J. Lanskap Indones., vol. 8, no. 2, 2016. 
[15] M. Winandari, M.I., \& Ischak, "Karakter Pengguna Ruang Publik di Taman Ayodjya Jakarta Selatan," J. Penelit. dan Karya Ilm. Arsit. Usakti “AGORA," vol. 16, no. 2, 2018.
[16] Wynveen, "Natural Area Visitors Place Meaning and Place Attachment Ascribed To A Marine Setting," J. Environ. Psychol., vol. 32, pp. 287296, 2012. 